\title{
Gauri as woman protagonist in Mulk Raj Anand's Novel
}

\author{
Dr. Shashi Yadav
}

\author{
Barkatullah University Institute of Technology \\ Barkatullah University, Bhopal
}

Email: shashi_uit@rediffmail.com

Keywords: Humanity, emancipation, hypocrisy, superstition, transformation, myths, meek, predicament, male chauvinism.

\begin{abstract}
Through this novel "Gauri" Mulk Raj Anand expresses his indisputable concern for the suffering humanity of India. It forces one to ask a few questions about the Indian character of woman. We call the woman as 'Mother', 'Goddess' and claim that our society always been given due respect to women. At the same time, we also beat them ablaze or turn them out of the house. Mulk Raj Anand's novel Gauri eloquently exposes the hypocrisy of our society. It not only voices a strong protest against ill treatment of women but also explores through the example of Gauri what woman in India should do for her emancipation.
\end{abstract}

\section{INTRODUCTION}

Mulk Raj Anand is one of the greatest novelist in Indian Writing in English. Indian Literature prior considered litterateurs pre-occupied in history and romance only. It was too far remove from reality and the people living in the Indian society. Mulk Raj Anand endeavoured to eradicate Indian literature in English from being called literature of fairy tales and fantasy.

Gauri is unique novel among Mulk Raj Anand work as it is only novel with a women protagonist. This novel is indeed all Mulk Raj Anand fiction, expresses his indisputable concern for the suffering humanity of India. It forces one to ask a few questions about the Indian character. We call our women Mata, Devi and Laxmi and claim that our society has always been giving due respect to women. At the same time, we also beat them, set them ablaze or turn them our of the house. Mulk Raj Anand's novels Gauri eloquently exposes the hypocrisy of our society. It not only voices a strong protest against ill treatment of women but also explores through the example of Gauri what woman in India should do for her emancipation.

Gauri is presented as a meek and gentle country woman who suffers silently all the hardships and injustices imposed on her by her mother, mother-in-law and even her husband till she meets the enlightened city doctor, under whose influence she grows glowingly, conscious of her intrinsic worth as an independent individual.

In the novel Mulk Raj Anand shows that the villagers are blinded by superstition and they mistake superstition for religion. Through the character of Gauri Anand shows how superstition victimizes her. Panchi, husband of Gauri who in the beginning proud of her homely and innocent appearance and her cow like meekness, forms a completely different picture of her under the influence of superstition planted in him by Kesero, mother in-law of Gauri.

In Gauri Mulk Raj Anand presents the strong plea for the identification and approval of women's rights. The novelist is sense of disbelief in the Christian perspective of vice, his emphasis on the value of compassion in human affinities, his criticism of the cash bond and his usual reproof of uncritical faith in superstition of karma, and god, these are the humanistic notes that from the plot of the novel. In our conventional socio-cultural malice the woman remain unrealized trapped caged and oppressed. The women need equality with men is the chief principle of Mulk Raj Anand humanism which runs round the plot of this novel. Mulk Raj Anand through the character of Panchi, husband of Gauri presented typical mentality of man, for his the girl "whom he could fold in his arms at night and kick during the day, who would adorn his house and help him with the land". 
The removal of the disabilities of the Indian women and their freedom from various forms of law, the land does not admit of inequality on the basis of sex, old social and psychological habits and the reactionary resistance of the orthodox sections of society militate against the law and so even at the turn of this century majority of the Indian women are still martyrs to the conventions of our society which is cruel to women. They are intended to gave advantages to the selfishness of man. They permit man to have many rights and freedom from which woman is excluded. They adopt different standards to judge the individual and social conduct of man and woman.

The technique of contrast adopted in the characterization of Panchi and Gauri successfully brings out the nobility of Gauri as against the meanness of Panchi and attack the ill treatment of Gauri. The Gauri is helpless at the beginning of the novel but at the end she emerges victorious. The transformation that has taken place in Gauri from an obedient, gentle and meek person, to one with a will of her own is indeed a triumph of womanhood. But the portraits of the suffering Gauri sulking on her string cot in a dark room, kicked and insulted by her mean husband and Gauri putting up a defence for her husband in front of friends and relatives may be more attractive than the deficient Gauri telling her husband "If am a curse on you. I will go away .... And if you will strike me again I will hit you back". Her strength of character is best seen in her unwavering love for Panchi and her silent resolution. "to get to the source of that antagonism and hatred which he showed to her".

Gauri is Mulk Raj Anand only novel using Hindu myth as part of technique. But he does it not as a concession to the revivalists but to prove that a new contemporary myth of the potential man is possible, as against the myths of Ramayana and Mahabharta. Mulk Raj Anand does not want to hide the fact that the framework of Gauri comes form the Ramayana. In the first chapter, there is reference to Sita. Before Gauri's departure at the end of marriage ceremony to her husband's home, Laxmi advises her daughter: "Be like Sita....". Toward the end of novel, Rakhi with sustained viciousness compare the care of Gauri with Sita and Asks: "When Sita was abducted by Ravan, and her husband went and fetched her back, what did people say?" Panchi is embarrassed by almost the same malicious talk from his old friend Damodar: "Ohe ja, look after her! She has come back, after her exile like Sita had stayed with Ravana!. Gauri's enemies as well as mere gossip-mongers compared her forced stay with the banker in Hoshiarpur to Ravan's abduction of Sita and her forced exile in Lanka crushed under this similar situations. Panchi challenges Gauri to give proof of her purity. At this painful climax in the novel, the parallelism between the Story of Gauri and Sita crumbles. Gauri assert that she is a sita of twentieth century quite different from the sita of Ramayana. In the Ramayana, the earth opens up and swallows Sita to save her from further humiliation. Though Gauri wishes: "the earth to open up to secure her as it had open up to receive Sita, the ground was hard and solid under her feet and showed no sign of opening upto prover her innocence ....".

She realizes that the only answer lay in forgetting Sita and taking the road to town. Mulk Raj Anand seems to be saying, here that in this modern era of existential struggle, man instead of blindly depending on the strength of old myth, must find strength in his own physical and mental power through hard work and devotion to duty. As the Gauri to takes the road to the town, they says that she waved her head to forget Sita. She seems to make a correct assessment of her era in which the Gods are no longer helpful to the helplessness and so she courageously goes towards the town to seek emancipation. The road she takes is a road to progress, free from the stumbling blocks of old myths. Gauri could hold her own way only through the education and qualification in nursing the education and qualification in nursing she has obtained and which ensures for her an employment. The solution Gauri finds against her predicament is the solution to the predicament of Indian women.Education can free her from the clutches of superstition and employment can give her economic independence and together these can ensure for her a life of dignity and freedom. 


\section{CONCLUSION}

Mulk Raj Anand is Gauri delineates the character of Sita in the person of Gauri, he partly succeeds in making her essentially human, naïve and lovable. Gauri is cow-like in her goodness and keeps up her essential naiveté and purity of character, so characteristic of an Indian woman. Instead of meekly submitting to the irrational demands of society. She takes the road to Hoshiarpur which is both a redemption from the inflexible social custom and age old bondage from male chauvinism. Gauri's character is drawn with expert strokes and her gradual initiation into defying the customary male- domination is as indeed an act of Self assertion. Gauri is not presented as a meek and docile woman. She shows her real power in the circumstances when they become seemingly uncongenial. She stands before the village elders and boldly resists the social sanctions and their rigidities and even spurns them all, at the end of the novel, she prefers to live in self-isolation and anonymity, rather than meekly submitting to the senseless social custom. For her, marriage is a social convenience, a taboo that she comes to know of it only at the fag end of her life.

\section{References}

[1] Mulk Raj Anand, The Old Woman and the Cow, Kutub-Popular, Bombay,1960.

[2] Mulk Raj Anand, Gauri, New Delhi, Arnold- Heinemann, 1984.

[3] Guru Prasad Thakur, Experimentation with Language in Indian Writing in English,(ed.) S.K.Desai, Kolhapur, 1974.

[4] Meenakshi Mukherjee, Beyond the village, Critical Essays on Indian Writing,(Eds.) M.K.Naik, S.K.Desai,1972.

[5] Ashok Kumar Bachchan, The Novels of Mulk Raj Anand: A new critical spectrum (ed) T.M.J.Indra Mohan,2005.

[6] Saros Cowasjee, So Many Freedoms, A study of major fiction of Mulk Raj Anand, Oxford University Press, New Delhi, 1977.

[7] K.R.S. Iyenger, Indian Writing in English, Sterling Publishers Pvt. Ltd. 1985. 